\title{
Dimensions of E-CRM: An Empirical Study on Hotels' Web Sites
}

\author{
Noor Raihan Ab Hamid ${ }^{1}$, Aw Yoke Cheng ${ }^{2}$ and Romiza Md Akhir ${ }^{1}$ \\ ${ }^{1}$ Faculty of Business Administration, University of Management and Technology (UMTECH), \\ Petaling Jaya, Selangor, Malaysia \\ ${ }^{2}$ Faculty of Business and Management, Asia Pacific University College of Technology and Innovation \\ (UCTI), Technology Park Malaysia, Kuala Lumpur, Malaysia
}

\begin{abstract}
Electronic consumer relationship management (E-CRM) features are among the main factors contributing to the success of any ecommerce Web sites. E-CRM programmes and implementation should focus on effectiveness of managing consumer relations on the Internet through effective use of Internet features either to deliver updated and accurate information, offering customer service support as well as providing personalized and value-added services. Thus, the aims of this research are to identify E-CRM dimensions and perceived important features from a consumers' perspective. The primary data for this research were collected through a questionnaire survey. To determine the dimensions of E-CRM, a factor analysis was performed. The findings reported 14 dimensions of E-CRM which were perceived as important elements affording consumers repeated visits and purchases. The limitations of the study and future directions of research are discussed herein.
\end{abstract}

Keywords: Electronic Customer Relationship Management, Hotels, Web sites, Retention.

\section{Introduction}

The business environment of the digital economy has evolved into competition which is based on speed, ability to innovate and forging strategic collaboration with industry players as well as consumers. The advent of advance technology such as the Internet and mobile applications enables companies, large or small to compete in a cost effective manner than ever before. In a service sector, where efficient coordination is found, information and communication are critical, the low-cost-highly- efficient Internet technology allows value adding and even personalized services to be delivered. Primarily, competition in hospitality and tourism industry is centred on delivering consumer value through quality services to domestic and international tourists. Developing an effective consumer relationship via technology platform such as Internet may assist in increased consumers' satisfaction, loyalty and retention. Indeed, consumer relationship management (CRM) has been regarded as one of the most important concepts in modern marketing. By far, managing consumer relationship with the advancement of Web 2.0 requires businesses to collaborate and engage with their consumers through purposeful use of technology, such as social media.

Malaysian markets have recently begun to understand the importance of electronic consumer relationship management (E-CRM)

Copyright (C) 2011 Noor Raihan Ab Hamid, Aw Yoke Cheng and Romiza Md Akhir. This is an open access article distributed under the Creative Commons Attribution License unported 3.0, which permits unrestricted use, distribution, and reproduction in any medium, provided that original work is properly cited. Contact author: Noor Raihan Ab Hamid. E-mail: raihan@umtech.edu.my 
(Ab Hamid, 2008; Loh 2000). The interest was led by traditional consumer management economics. It costs the industry five times as much to acquire a new consumer than to retain an existing one; therefore, building long-term and sustainable consumer relationships was a good strategy, from the point of view of both building lifetime value relationships and business cost savings involved (Peppers and Rogers 1996). Khatibi et. al., (2002) found that there is a positive trend of increasing awareness of the benefits of Internet marketing. Factors, such as global access and ubiquity, convenience, increased product information and availability of value-added services on the Internet were cited as contributing factors of enhancing consumer satisfaction and loyalty in the cyberspace (Ab Hamid et al, 2010).

This research aims to identify the consumers preferred features and services of hotels Web sites leading to repeat visits and purchases. Premised on the belief that delighted consumers are likely to return and become loyal to service providers, this study adapted the E-CRM dimensions proposed by $\mathrm{Ab}$ Hamid and McGrath (2005) to empirically identify the dimensions and features of ECRM relevant to the hotel industry. In an intense competition, it is crucial for hotel operators to understand the elements which are perceived as important in influencing consumers' repatronage behaviour. Hence, a study to ascertain the hotels Web sites service attributes and dimensions perceived important from consumers' evaluation is worthwhile. This research was carried out as a pilot study to determine the reliability and validity of the measurement scales used, which were adapted from E-CRM dimensions proposed by Ab Hamid and McGrath (2005).

\section{Relationship Marketing and the Hotel Industry}

\section{Growth of the Hotel Industry}

Hotel service is one of the most important sectors of hospitality and tourism industry contributing significantly to the economic growth in Malaysia. According to Tourism Malaysia (2011), there were 24.6 million tourists who have visited Malaysia and in turn contributed with MYR 56.5 billion receipts to the country in year 2010 as compared to 23.6 million tourists and with MYR 53.4 billion receipts in the previous year. The arrivals were largely from the Association of South-East Asian Nations (ASEAN) countries which recorded $77.8 \%$. Despite the gradual growth of tourist arrival to Malaysia, the overall hotel occupancy in Malaysia has recorded a slight reversal of growth in year 2010. Much of the decline was due to the recent global economic crisis most of which effect was felt in the early quarters of 2010. The hotel occupancy rates in year 2010 as compared to year 2009 has shown slight decline of 1.6 percent for the whole of Malaysia, however metropolitan areas such as the Klang Valley were not affected by this downturn. For example, in Kuala Lumpur, Selangor, and Putrajaya, the occupancy rates have increased 4.2 percent, 2.4 percent and 1.4 percent respectively (Tourism Malaysia, 2011).

Indeed the slight decline has called for serious attention from the hotel operators to rethink the importance of building tourist (consumer) relationship. One of the ways to strategize is to aggressively plan for relationship marketing through various marketing channels including the Internet.

\section{Electronic Consumer Relationship Management (E-CRM)}

According to Grönroos (1994) service firms by their inherent characteristics of inseparable production and consumption possess the elements necessary to forge relationships with consumers. Because most companies offer almost the same core product/services, differentiation will be of greater interest to companies with the strongest capability to develop long-term consumer relationships (Zineldin, 1999). Consumers perceived that service quality, satisfaction and value have played an important role in service management 
(traditionally) in the context of online businesses, so a holistic and multi-purpose view of the whole relationship is required (Holmlund \& Strandvik, 1999; Luck \& Lancaster, 2003).

In a study of the current use of the Internet as a marketing tool in the hotel industry, Gilbert et al. (1999) present an argument for the application of the RM model as a framework for the development of hotel Web sites. They contend that hotels need a framework that can bridge the gap between simply connecting to the Web and harnessing its power for competitive advantage. However, the pursuit of the marketing objective will be constrained by the possibilities presented within the hotel's market area, the hotel's location and its current product positioning (Jeffrey and Barden, 2000). WebProbe claims that if hoteliers know more about their visitors, they will be able to redesign their sites to help them build stronger relationships with them. Geoffrey Breeze, vice-president of marketing at Hilton International maintains that hotels have far more information about their guests than they can actually use (Caterer \& Hotelkeeper, 2001).

Drawn from previous literature, this study investigated perceived important E-CRM dimensions and features in managing consumer relations. Ab Hamid and McGrath (2005) reported 12 dimensions of E-CRM program namely: information quality, ease of navigation, consumer service quality, fulfilment, integrated marketing channels, online community, rewards, personalization level, site security, value-added services, perceived trust and price attractiveness.

The following paragraph describes Ab Hamid and McGrath (2005) dimensions of E-CRM:-

\section{a) Information Quality}

Based on information systems literature, information quality is a reflection of relevancy, recency, sufficiency, consistency and understandability. Since a consumer's decision making efficiency improves when searching is simplified, information presented on the sites should be easy to understand and up-to-date.

\section{b) Ease of Navigation}

In brief, ease of navigation includes both good organization (format) of the content layout as well as simple-to-use navigation (ease of use). Sites that are easy to navigate offer quick access to information needed with minimized effort.

\section{c) Consumer Service Quality}

Consumers constantly demand for careful, continuous, useful communication with company representatives. Since these attributes are frequently identified as salient dimensions in store selection behaviour, company representatives should have the knowledge and basic technology skills to answer online questions. They should understand consumer-specific needs, have the capacity to handle problems that arise and address consumer complaints in a friendly manner.

\section{d) Fulfilment}

The order fulfilment process is concerned with delivering the right product at the right time and responding to consumer inquiries.

\section{e) Integrated Marketing Channels}

For click-and-mortar companies, integration of the virtual and physical operations is crucial to ensure continuous consumer relationships in both channels. This is because consumers want to be able to deal with companies as single entities. They also expect to get the same consumer service level via all channels.

\section{f) Online Community}

Consumers can exchange information with each other and obtain online help from their online members when a product- related 
problem arises. These experiences create stickiness - the extent to which a company is able to attract consumers to use a site relatively longer and return, and consumers are more likely to revisit the site.

\section{g) Rewards}

Reward is another attribute deemed important to attracting consumers to repatronize. Reward programs allow consumers to collect points for every purchase from or visit to a site, in exchange for free gifts, coupons or cash rebates. The program also provides greater membership privileges for returning consumers.

\section{h) Personalization Level}

Personalization attracts consumers to come back repetitively since it turns consumers into product 'makers' rather than simply product 'takers' (Winer 2001), Thus, consumers are empowered in ways that they can choose their own preferred design, colour, product updates and other attributes that go well with their tastes.

\section{i) Site Security}

Consumers are concerned about online payment security, reliability and privacy policy since they have to provide their personal details and credit card information in the ordering process. This concern increases the perception of risk and simultaneously reduces the level of trust in an online company, which in turn adversely affects satisfaction. Hence, online companies that clearly communicate to consumers on how their private and transaction data are secured are more likely to benefit from increased consumer satisfaction (Ab Hamid et al., 2010).

\section{j) Value-added Services}

Consumers will feel empowered and in control when they are able to easily find product/service, learn more about it and quickly make a purchase decision. For example, a site may provide features such as shopping carts, one-click ordering and order tracking to provide superior convenience and higher levels of consumer control.

\section{k) Perceived Trust}

Since online transactions are associated with perceived risk, trust and confidence in the firm seem imperative in a consumer's decision making. Assurance of security in using the Web can be done by implementing security features such as digital certificates, secure servers and third party trusting agencies.

\section{l) Price Attractiveness}

Online consumers can easily compare prices across e-tailers (retailers who use the Internet as their only marketing channel). Consequently, if a price paid is higher than what is found in other e-tailers for a similar product, the consumer is significantly less satisfied.

\section{Research Framework}

\section{Questionnaire Design}

We designed the questionnaire used in this study based on the research objectives discussed. The questionnaire consisted of two parts namely Section A and B. The first part, Section A, consisted of consumers opinion about the features they perceive as important on hotels Web sites which will induce repeated visits or purchases. Section B contained demographic information such as respondent age group and income level. These questions included respondents access location, number of years using the Internet, types of Internet activities and time spent in a week on the Internet. A 5-point labelled Likert type scale was used with anchor from $1=$ "Most important" to $5=$ "Not important at all".

Ab Hamid and McGrath (2005) conducted a study on E-CRM on Web sites in general and reported 12 salient dimensions. It is deemed 
appropriate to adapt $\mathrm{Ab}$ Hamid and McGrath's (2005) model since most of the dimensions are commonly found on Web sites. Additionally, extending from $\mathrm{Ab}$ Hamid and McGrath's (2005) model, this research investigated other items which were deemed appropriate for the hotel industry such as reservation tracking, and current trend of the Internet, that is the use of social media features. Consequently, a total of 69 items were used to test consumers' opinion on perceived important features of E-CRM on hotels Web sites.

\section{Sampling}

This research served as a pilot test to assess the measurement scales in terms of their reliability and validity which will be used for further study of the subject matter. Primary data for this research were collected using personally-administered questionnaires as this method will ensure a higher response rate. Research assistants helped in contacting respondents via email, and distributing and collecting the questionnaire in person. Secondary data for this study came mainly from newspapers, journals, publications, magazines, and books accessed via the Internet.

The main source of users list came from various education, government and corporate institutions in Klang Valley, Penang, Johor Bahru and Kuching. The nature of work that people do in these institutions requires the use of Internet; hence they are appropriate source of primary data for this study. For example, it is common for university staff and students to use the internet for communication or to conduct research. Likewise, most companies in the selected cities have internet connections on their premises and the method of communication within these companies is mainly email. Thus, the choices of these institutions are deemed appropriate for this study. For the purpose of the pilot test, 200 respondents were chosen using purposive (judgment) sampling, as the sample should have experience in surfing hotels Web sites. A total of 162 (81\%) responded to the survey while the remaining respondents could not be contacted or declined to participate. Descriptive analysis was used to report the profile of research respondents while exploratory factor analysis was conducted to examine the dimensions of E-CRM.

\section{Research Methods and Design}

\section{Data Analysis and Results}

Frequency distributions were calculated for all individuals in this research and are summarised in Table 1. As indicated, the respondents were almost evenly split by gender (57 per cent male and 43 per cent female). Most of the respondents were 21 to 30 years of age (77 per cent), followed by the age groups of below 20 years and 31 to 40 at 10 per cent and 7 per cent, respectively. These three groups contributed approximately 87 per cent of the overall total in terms of age. 70 per cent of the respondents had spent at least 15 years in education and held a bachelor's degree. Most of the respondents were working adults (86 per cent) and earned between MYR 24000 48000 per annum (69 per cent). 
Table 1: Respondent Profile

\begin{tabular}{|c|c|c|c|c|c|c|}
\hline Items & $\begin{array}{c}\text { No. of } \\
\text { Respondents }\end{array}$ & $\%$ & & Items & $\begin{array}{c}\text { No. of } \\
\text { Respondents }\end{array}$ & $\%$ \\
\hline 1 Gender & & & & Occupation & & \\
\hline - Male & 76 & 57 & & - Student & 16 & 12 \\
\hline - Female & 58 & 43 & & - Non Executive & 3 & 2 \\
\hline 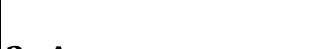 & & & & - Executive & 112 & 84 \\
\hline 2. Age & & & & & & \\
\hline - Below 20 years & 14 & 10 & & - Pensioner & 3 & 2 \\
\hline - $21-30$ years & 103 & 77 & 5. & Monthly income & & \\
\hline - $31-40$ years & 9 & 7 & & - less than MYR 2000 & 19 & 14 \\
\hline - $\quad 41-50$ years & 7 & 5 & & - MYR 2000 - MYR 4000 & 93 & 69 \\
\hline - Above 50 years & 1 & 1 & & - MYR 4001 -MYR 6000 & 10 & 8 \\
\hline & & & & - MYR 6001 and above & 12 & 9 \\
\hline $\begin{array}{l}\text { 3. Education level } \\
- \text { SPM }\end{array}$ & 5 & 4 & 6. & Race & & \\
\hline- & 25 & 19 & & - Malay & 12 & 9 \\
\hline STPM/Dip/Matrices & & & & & & \\
\hline - Degree & 94 & 70 & & - Chinese & 48 & 36 \\
\hline - Masters & 8 & 6 & & - Indian & 12 & 9 \\
\hline$-\mathrm{PhD}$ & 1 & 1 & & - Others & 62 & 46 \\
\hline - Others & 1 & 1 & & & & \\
\hline
\end{tabular}

\section{Factor Analysis}

A principal component analysis (PCA) was performed on the data set to reduce a large number of observed variables into a smaller number of factors measuring different constructs. 69 items were used to operationalize the variables and to discern the salient dimension of E-CRM under study. Based on the Eigenvalue of more than $1.0 \mathrm{a}$ Varimax rotation yielded 14 dimensions of ECRM for hotels Web sites namely ease of navigation; information quality; customer service efficiency; payment options; personalization level; rewards; channel integration; use of social media; security and privacy policy; multimedia features; reservation and tracking; lower rates; fulfilment of service and quality services.

Table 2 shows the list of E-CRM dimensions and the Cronbach's alpha values. The alpha values indicated that the scales used to measure the dimensions were acceptable (> 0.60). 
Table 2: List of E-CRM Dimensions for Hotels Web Sites

\begin{tabular}{|l|c|}
\hline Factors/Dimensions & $\begin{array}{c}\text { Cronbach's } \\
\text { Alpha Value }\end{array}$ \\
\hline Information quality & 0.64 \\
\hline Quality services & 0.68 \\
\hline Ease of navigation & 0.79 \\
\hline Consumer service efficiency & 0.72 \\
\hline Payment options & 0.64 \\
\hline Security and privacy policy & 0.62 \\
\hline Multimedia features & 0.69 \\
\hline Personalization level & 0.66 \\
\hline Rewards & 0.86 \\
\hline Channel integration & 0.65 \\
\hline Reservation and tracking & 0.79 \\
\hline Use of social media & 0.87 \\
\hline Lower rates & 0.77 \\
\hline Fulfilment of service & 0.85 \\
\hline
\end{tabular}

\section{Discussion and Conclusion}

In order to be competitive, hotel operators should strive for adding value in their offerings on hotels' Web sites. Providing features such as reservation and modification to reservation facility, tracking transactions history, allowing some degree of personalization, and understanding consumers' specific needs and preferences enhance consumers' perceived value, thus increase loyalty. Apparently, the use of social media is gaining popularity and the trends are showing more literate and younger consumers becoming keen users of the new marketing channel. This study shows that consumers viewed hotels Web sites sharing past consumers' reviews through Blogs and Facebook as one of the important elements leading to intention to revisit.

Besides, consumer service quality should be given a top priority since it is the first contact point for consumers to evaluate whether a firm is reliable or not. When one finds difficulty in communicating with the consumer service; that is either an enquiry is not attended to within a reasonable time or the representative appears to have insufficient knowledge, he/she would immediately make an adverse evaluation about a firm's service performance. In a highly competitive environment such as the Internet, this unpleasant experience (leading to dissatisfaction) would leave firms losing not only one potential consumer but perhaps many more, due to "word-of-mouth". Hence, firms are well advised to attend to consumer complaints efficiently, clearly display the links to consumer service and help desk, and to have a consumer service representative always available.

Next, the quality of information should be another important attribute that firms should be concerned with. Since Internet technology stems from computer technology, which is believed to process and deliver information at speed, the relevancy and accuracy of information seem to be compulsory criteria of a Web site. A site that displays information that has expired at a point of time may be viewed as inefficient. In addition, it is vital for hotel operators to accurately capture and deliver services within consumers' expectations. Failure to fulfil services as per consumers' expectations will result in not only consumers' frustration but will adversely affect consumers' assessment of firms' performance. Then, 
ease of site navigation is also vital. Generally, Internet consumers are impatient, hence loading speed of the site, simplicity of use and accessibility are critical.

In this study, respondents were asked to recollect their experience of hotels Web sites. More in depth studies could be carried out to investigate the use of E-CRM in industryspecific environment such as financial sector, entertainment, health, government and education sector since E-CRM may imply different meanings from one industry to another. The sample respondents from this study were mainly working adults at executive level that have higher purchasing power. Future studies should be conducted to assess the opinions of younger adults who seem to have greater dependence on technology and higher literacy. Since this group of consumers would form a different market segment in the near future and may have different perception of matters of importance, studies to understand their behaviour and expectations of service are worthwhile. This study is concerned with consumers' perceived important features of E-CRM entailing consumers repeated visits and purchases. Although companies are well advised to adopt an E-CRM strategy, its implementation may vary depending on the business scale. For example, budget hotels may not be able to fully utilize the potential of Internet technology due to constraints in resources. Hence, E-CRM implementation in various business scenario merits further investigation.

\section{Acknowledgment}

The authors would like to express gratitude to the Ministry of Higher Education (MOHE), Malaysia, for giving the researchers the opportunity to conduct the research successfully. The support has enabled the researchers to pursue their goals and meet the objectives of this research. Appreciation also goes to the Faculty of Business Administration of the University of Management and Technology, and the Faculty of Business and Management of the Asia Pacific University College of Technology and Innovation, in providing facilities during the conduct of this research.

\section{References}

Ab Hamid, N. R. (2008). “Consumers' Behaviour Towards Internet Technology and Internet Marketing Tools," International Journal of Communications, 2(3), 195-204.

Ab Hamid, N. R, \& Kassim, N. (2004). 'Internet Technology as a Tool in Managing Customer Relationships,' The Journal of American Academy of Business Cambridge, 4 (1 \&2), 103-108.

Ab Hamid, N. R. \& Khatibi, A. A. (2006). 'Perceived Risk and Users' Experience Influence on Internet Technology Adoption,' WSEAS Transactions on Systems, 5 (12), 2766-2773.

Ab Hamid, N. R. \& McGrath, G. M. (2005). 'The Diffusion of Internet's Interactivity on E-tail Web Sites: A Customer Relationship Model,' Communications of the International Information Management Association, 2, 4570.

Ab Hamid, N. R., McGrath, G. M. \& Khatibi, A. (2007). 'Retaining Online Consumers: Evidence from South East Asia,' WSEAS Transactions on Systems, 6(3), 541-548.

Ab Hamid, N. R, Md Akhir, R. \& Mashudi, P. M. (2010). 'An Assessment of the Internet's Potential in Enhancing Customer Relations,' International Journal of Arts and Sciences, 3(12), 265-281.

Anton, J. \& Hoeck, M. (2002). 'E-Business Customer Service,' The Anton Press, Santa Monica, CA.

Arnott, D. C. \& Bridgewater, S. (2002). "Internet, Interaction and Implications for Marketing," Marketing Intelligence and Planning, 20 (2), 86-95. 
Baloglu, S. \& Pekcan, Y. (2005). 'The Web Design and Internet Site Marketing Practices of Upscale and Luxury Hotels in Turkey,' Tourism Management.

Bradshaw, D. \& Brash, C. (2001). "Managing Customer Relationships in the e-business World: How to Personalize Computer Relationships for Increased Profitability," International Journal of Retail and Distribution Management, 29, 520-529.

Burger, F. (1997). 'Web-database Supported Tourist Information on the Web,' in Tjoa, A.M. (Eds),Conference Proceedings: Information and Communication Technologies in Tourism, Springer, Wien, 3946.

Cai, L., Card, J. A. \& Cole, S. T. (2004). “Content Delivery Performance of World Wide Web Sites of US Tour Operators Focusing on Destinations in China," Tourism Management, 25(2), 219-27.

Calongne, C. M. (2001). "Designing for Web Site Usability," Proceedings of the 7th Annual Consortium for Computing in Small Colleges, Central Plains Conference on The Journal of Computing in Small Colleges, 39-45.

Chen, I. J \& Popovich, K. (2003). "Understanding Customer Relationship Management (CRM): People, Process and Technology," Journal of Business Process Management, 9(5), 672-688.

http://dx.doi.org.proxy.unitar.edu.my/10.101 6/S0278-4319\%2802\%2900076-2

Chung, T., \& Law, R. (2003). "Developing a Performance Indicator for Hotel Websites," International Journal of Hospitality Management, 22 (1), 119-25.

Deimezi, O. \& Buhalis, D. (2003). 'E-tourism and Developments in Greece,' Information and Communication Technologies in Tourism, Springer Verlag, Wien, 39-48.

Feinberg, R., \& Kadam, R. (2002). "E-CRM Web Service Attributes as Determinants of
Customer Satisfaction with Retail Web Sites," International Journal of Service Industry Management, 13, 432-451.

Economic Planning Unit of the Prime Minister Office, Government of Malaysia (2011). "The Malaysian Economy in Figures 2010,": External Sectors, [Online] [Retrieved: February 28, 2011],

http://www.epu.gov.my/c/document_library /get_file?uuid=4f4dea61-0446-4803-b52f65e85a37c5fe\&groupId=34492

Gatsiounis, I. (2010). "Local Chains Sitting Out Hotel and travel Boom in Malaysia," Forbes Asia Magazine, [Online] [Retrieved: February 28, 2011], http://www.forbes.com

Gratzer, M. \& Winiwarter, W. (2003). "The Role of the Internet in the SME Hotel Sector in Austria," Lecture Notes in Computer Science, 27(13), 85-95.

Gurau, C. (2003). "Tailoring e-service Quality through CRM," Managing Service Quality, 13, 520-531.

Heichler, E. (1997). "Internet Lacks Content for Women," Computer World , 31(19), 17.

Heung, V.C.S., (2003). "Internet Usage by International Travelers: Reasons and Barriers," International Journal of Contemporary Hospitality Management , 15(7), 370-378.

Ho, J. (1997). 'Evaluating the World Wide Web: A Study of 1,000 Commercial Sites,' Journal of Computer Mediated Communication, 3(1), [Online] [Retrieved: February 28, 2011], www.ascusc.org./jcmc/vol3/issue1/ho.html

Huizingh, E. K. R. E.(2000). "The Content and Design of Web Sites: An Empirical Study," Information \& Management, 37(3), 123-34.

Jeong, M. \& Lambert, C. U. (2001). "Adaptation of an Information Quality Framework to Measure Customers' Behavioural Intentions to Use Lodging Web 
Sites," International Journal of Hospitality Management, 20(2), 129-46.

Kandampully, J. \& Duddy, R. (1999). "Relationship Marketing: A Concept Beyond Primary Relationship," Marketing Intelligence \& Planning, 17(7).

Khatibi, A. A, Ismail, H . \& Thyagarajan, V. (2002). "What Drives Customer Loyalty: An Analysis from the Hotels Industry," Journal of Targeting, Measurement and Analysis for Marketing, 11(1), 34-44.

Law, R. \& Hsu, C. H. (2005). "Customers' Perceptions on the Importance of Hotel Web Site Dimensions and Attributes," International Journal of Contemporary Hospitality Management, 17(6), 493-503.

Lee, J, Lee, J. \& Feick, L. (2001). "The Impact of Switching Costs on the Customer Satisfaction-loyalty Link: Mobile Phone Service in France," Journal of Services Marketing, 15, 35-48.

Liang, K. \& Law, R. (2003). "A Modified Functionality Performance Evaluation Model for Evaluating the Performance of China Based Hotel Web Sites," Journal of the Academy of Business and Economics, [Online] [Retrieved: February 28, 2011], www.findarticles.com.

Lodhia, S. (2004). "Corporate Environmental Reporting Media: A Case for the World Wide Web," Electronic Green Journal, 20, [Online] [Retrieved: February 28, 2011], http://egj.lib.uidaho.edu/egj20/lodhi a1.html

Loh, C. J. (2000, September 6). 'Using CRM Tools to Attract Customers,' New Straits Times, Kuala Lumpur, 10.

Luck, D. \& Lancaster, G. (2003). "E-CRM: Customer Relationship Marketing in the Hotel Industry," Managerial Auditing Journal, 18(3), 213-231.

Mahfouz, A. (2000). "Web Sites Interface Design: External and Internal Factors," in
Reich, S., Anderson, K.M. (Eds), Open Hypermedia Systems and Structural Computing, Proceedings of the 6th International Workshop, OHS-6, 2nd International Workshop, SC-2, San Antonio, Texas, 30 May-4 June, 46.

Malaysian Science and Technology Information Centre. (2008). 'Malaysian Facts and Figures,' [Online] [Retrieved: February 5, 2009], http://www.mastic.gov.my

Morrison, A. M., Taylor, S., Morrison, A. J. \& Morrison, A. D. (1999). "Marketing Small Hotels on the World Wide Web," Information Technology and Tourism, 2(2), 97-113.

Murphy, J., Forrest, E. J., Wotring, C. E. \& Brymer, R. A. (1996). "Hotel Management and Marketing on the Internet," The Cornell Hotel and Restaurant Administration Quarterly, 37 (3), 70-82.

Ness, J. A., Schroeck, M. J., Letendre, R. A. \& Douglas, W. J. (2001). 'The Role of ABM in Measuring Customer Value,' Strategic Finance, 82, (9), 32-37.

O'Connor, P. (2003). "On-line Pricing: An Analysis of Hotel-company Practices," Cornell Hotel and Restaurant Administration Quarterly, Vol. 44 (1), 88-96.

Parets, R. (2002, August). 'Getting the Word out: Profiting from Smart Internet Marketing isn't Just for the Big Boys,' Lodging Magazine, 37-38.

Rachman, Z. \& Buchanan, J. (1999). Effective Tourism Websites, Part 1: Literature Review and Features Surveys [Online] [Retrieved: February 28, 2011], http://mngt.waikato.ac.nz/depts/mns s/john

Rachman, Z. M. \& Richins, H. (1997). "The Status of New Zealand Tour Operator Web Sites," The Journal of Tourism Studies, 8 (2), 62-82.

Rosen, D. E. \& Purinton, E. (2004). "Web Site Design: Viewing the Web as a Cognitive 
Landscape," Journal of Business Research, 57 (7), 787-94.

Sigala, M. (2003a).'Competing in the Virtual Marketspace: A Strategic Model for Developing e-commerce in the Hotel Industry,' International Journal of Hospitality Information Technology, 3 (1), 43-60.

Sigala, M. (2003b). "Developing and Benchmarking Internet Marketing Strategies in the Hotel Sector in Greece," Journal of Hospitality \& Tourism Research, 27(4), 375401.

Sharif, R. (2004a, April 7). 'Malaysian Surfers: Online Banking is Hot, Shopping So-so,' The Star Online, [Online] [Retrieved: December 4, 2008], http://thestar.com.my.

Sharif, R. (2004b, April 27). 'IDC: Strong IT Spending this Year,' The Star Online, [Online] [Retrieved: December 4, 2008], http://thestar.com.my.

Sharif, R. (2004c, August 30). 'Online Banking Getting more Popular,' The Star Online, [Online] [Retrieved: December 4, 2008], http://thestar.com.my.

Suki, N. B. M., Ahmad, M. I. \& Thyagarajan, V. (2002). "Motivation and Concern Factors for Internet Shopping: A Malaysian Perspective," The Electronic Journal for E-commerce Tools and Applications, 1, 1-18.

The Star Online. (2004, November 26). 'IT investment: Promising outlook for Malaysia,' [Online] [Retrieved: December 4, 2008], http://thestar.com.my.

Tourism Malaysia. (2011). "Facts and Figures 2010," [Online] [Retrieved: February 28, 2011],

http://corporate.tourism.gov.my/research.as p?page=facts_figures

Tourism Malaysia. (2011). 'Malaysia Average Hotel Occupancy Rates,' Tourism Malaysia, [Online] [Retrieved: March 31, 2011], http://corporate.tourism.gov.my/tourismma laysia_corpx/rpt3_hoteloccupancy.cfm?rpt=3

Van der Merwe, R. \& Bekker, J. (2003). “A Framework and Methodology for Evaluating e-commerce Web Sites," Internet Research: Electronic Networking Application and Policy, Vol. 13 No.5, pp.330-41.

Van Hoof, H., Ruys, H. \& Combrink, T. (1999). "Global Hoteliers and the Internet: Use and Perceptions," International Journal of Hospitality Information Technology, 1 (1), 4561.

Wan, H. (2000). "Opportunities to Enhance a Commercial Web Site," Information \& Management, 38(1), 15-21.

Weeks, P. \& Crouch, I. (1999). "Sites for Sore Eyes: An Analysis of Australian Tourism and Hospitality Web Sites," Information Technology and Tourism, 2, 153-72.

Wei, S., Ruys, H. F., van Hoof, H. B. \& Combrink, T. E. (2001). "Uses of the Internet in the Global Hotel Industry," Journal of Business Research, 54(3), 235-41.

Winer, R. S. (2001). Customer Relationship Management: A Framework, Research Directions and the Future, Haas School of Business, University of California, Berkeley.

Zafiropoulos, C., Vrana, V. \& Paschaloudis, D. (2006). "The Internet Practices of Hotel Companies: An Analysis from Greece," 18(2), 156-163.

Zineldin, M. (2000). "Beyond Relationship Marketing: Technologicalship Marketing," Journal of Marketing Intelligence \& Planning, 18, (1), 9-23. 
Exhibit: Detail results of the Factor Analysis

\begin{tabular}{|c|c|c|c|c|}
\hline \multirow[t]{2}{*}{ Items } & \multicolumn{4}{|c|}{ Dimensions } \\
\hline & $\begin{array}{c}\text { Ease of } \\
\text { Navigation }\end{array}$ & $\begin{array}{l}\text { Information } \\
\text { quality }\end{array}$ & $\begin{array}{c}\text { Customer service } \\
\text { efficiency }\end{array}$ & $\begin{array}{l}\text { Payment } \\
\text { options }\end{array}$ \\
\hline Website is always easily accessible & 0.453 & & & \\
\hline $\begin{array}{l}\text { Website provides easy steps whenever } \\
\text { a customer needs to register }\end{array}$ & 0.609 & & & \\
\hline $\begin{array}{l}\text { Only a few clicks to get to the information } \\
\text { needed }\end{array}$ & 0.695 & & & \\
\hline Web pages load quickly & 0.651 & & & \\
\hline Links to information are clearly displayed & 0.653 & & & \\
\hline $\begin{array}{l}\text { Website uses a language that can be easily } \\
\text { understood }\end{array}$ & 0.533 & & & \\
\hline Website offers multiple language options & 0.603 & & & \\
\hline Website URL address is easy to remember & 0.595 & & & \\
\hline Information displayed is accurate & & 0.719 & & \\
\hline $\begin{array}{l}\text { The site provides in-depth information on } \\
\text { services }\end{array}$ & & 0.837 & & \\
\hline Information displayed is easy to understand & & 0.426 & & \\
\hline Complaints are handled professionally & & & 0.663 & \\
\hline Receive confirmation on my reservation & & & 0.445 & \\
\hline Customer service responds within 48 hours & & & 0.644 & \\
\hline $\begin{array}{l}\text { Customer service is professional in answering } \\
\text { enquiries }\end{array}$ & & & 0.534 & \\
\hline $\begin{array}{l}\text { Customer service will inform if there is any } \\
\text { problem with reservation }\end{array}$ & & & 0.477 & \\
\hline
\end{tabular}

\begin{tabular}{|l|l|l|l|c|}
\hline \multirow{2}{*}{ Items } & \multicolumn{3}{c|}{ Dimensions } \\
\cline { 2 - 5 } & $\begin{array}{c}\text { Ease of } \\
\text { Navigation }\end{array}$ & $\begin{array}{c}\text { Information } \\
\text { quality }\end{array}$ & $\begin{array}{c}\text { Customer } \\
\text { service } \\
\text { efficiency }\end{array}$ & $\begin{array}{c}\text { Payment } \\
\text { options }\end{array}$ \\
\hline $\begin{array}{l}\text { Website provides various credit card } \\
\text { options }\end{array}$ & & & & 0.615 \\
\hline $\begin{array}{l}\text { for customers paying with a credit } \\
\text { card }\end{array}$ & & & & \\
\hline $\begin{array}{l}\text { (eg. Visa, Mastercard, Diners Club, } \\
\text { AMEX) }\end{array}$ & & & & 0.721 \\
\hline $\begin{array}{l}\text { Website provides alternative } \\
\text { payment method }\end{array}$ & & & & \\
\hline $\begin{array}{l}\text { other than credit card (PayPal, EPX, } \\
\text { auto debit, }\end{array}$ & & & & \\
\hline money order,etc) & & & & \\
\hline
\end{tabular}




\begin{tabular}{|c|c|c|c|c|}
\hline \multirow[t]{2}{*}{ Items } & \multicolumn{4}{|c|}{ Dimensions } \\
\hline & $\begin{array}{l}\text { Personalization } \\
\quad \text { level }\end{array}$ & Rewards & Channel Integration & $\begin{array}{l}\text { Use of } \\
\text { Social } \\
\text { media }\end{array}$ \\
\hline Website allows me to view my transaction history & 0.333 & & & \\
\hline $\begin{array}{l}\text { Receive promotional information that match my } \\
\text { interests }\end{array}$ & 0.683 & & & \\
\hline Website allows visitor to create "My Profile/ Account & 0.545 & & & \\
\hline $\begin{array}{l}\text { Hotel website offers attractive rewards for } \\
\text { returning to the site }\end{array}$ & & 0.595 & & \\
\hline $\begin{array}{l}\text { Website offers attractive cash rebates for any } \\
\text { online purchase }\end{array}$ & & 0.811 & & \\
\hline $\begin{array}{l}\text { Website offers attractive points redemption for any } \\
\text { online purchase }\end{array}$ & & 0.784 & & \\
\hline Website offers attractive gifts for any online purchase & & 0.845 & & \\
\hline The site often offers attractive discounts & & 0.725 & & \\
\hline $\begin{array}{l}\text { Check orders placed on the internet through physical } \\
\text { channels }\end{array}$ & & & 0.756 & \\
\hline $\begin{array}{l}\text { Check reservations made via telephone or other } \\
\text { physical channel through the website }\end{array}$ & & & 0.448 & \\
\hline \multirow[t]{2}{*}{ Items } & \multicolumn{4}{|c|}{ Dimensions } \\
\hline & $\begin{array}{l}\text { Personalization } \\
\text { level }\end{array}$ & Rewards & Channel Integration & $\begin{array}{l}\text { Use of } \\
\text { Social } \\
\text { media }\end{array}$ \\
\hline $\begin{array}{l}\text { Cancel/modify reservations made over the telephone } \\
\text { via the hotel website }\end{array}$ & & & 0.776 & \\
\hline $\begin{array}{l}\text { Cancel / modify reservations made via website by } \\
\text { contacting customer representative through } \\
\text { telephone }\end{array}$ & & & 0.832 & \\
\hline $\begin{array}{l}\text { Hotel uses social media tool such as facebook, } \\
\text { blogs, twitter,etc }\end{array}$ & & & & 0.755 \\
\hline $\begin{array}{l}\text { Share/exchange information with other hotel guests } \\
\text { in the social media platform }\end{array}$ & & & & 0.716 \\
\hline $\begin{array}{l}\text { Obtain useful information about the hotel from online } \\
\text { members from the social media }\end{array}$ & & & & 0.652 \\
\hline Hotel website has links to the hotels social media & & & & 0.856 \\
\hline Hotel makes good use of social media & & & & 0.857 \\
\hline Comments from social media are useful to me & & & & 0.578 \\
\hline
\end{tabular}




\begin{tabular}{|c|c|c|c|}
\hline \multirow[t]{2}{*}{ Items } & \multicolumn{3}{|c|}{ Dimensions } \\
\hline & Security and Privacy Policy & Multimedia Features & $\begin{array}{l}\text { Reservation } \\
\text { and Tracking }\end{array}$ \\
\hline Website imposes a strict privacy policy & 0.455 & & \\
\hline $\begin{array}{l}\text { Site provides a third party verification (eg. seal } \\
\text { of } \\
\text { approval) to endorse website strict security } \\
\text { standard }\end{array}$ & 0.639 & & \\
\hline High security standard over transaction data & 0.515 & & \\
\hline Website offers entertainment features & & 0.318 & \\
\hline $\begin{array}{l}\text { Hotel website has background music which is } \\
\text { pleasant to listen to }\end{array}$ & & 0.358 & \\
\hline Website displays attractive pictures & & 0.801 & \\
\hline $\begin{array}{l}\text { Website has the multimedia and animation } \\
\text { effects }\end{array}$ & & 0.734 & \\
\hline Items & \multicolumn{3}{|c|}{ Dimensions } \\
\hline & Security and Privacy Policy & Multimedia Features & $\begin{array}{l}\text { Reservation } \\
\text { and Tracking }\end{array}$ \\
\hline Company allows to view my reservation & & & 0.838 \\
\hline $\begin{array}{l}\text { Make changes to online reservation without } \\
\text { much hassle }\end{array}$ & & & 0.351 \\
\hline $\begin{array}{l}\text { Hotel website has links to the hotels social } \\
\text { media }\end{array}$ & & & 0.311 \\
\hline $\begin{array}{l}\text { Hotel website keeps a history of my } \\
\text { transactions }\end{array}$ & & & 0.820 \\
\hline $\begin{array}{l}\text { I can request for services based on my } \\
\text { preferences }\end{array}$ & & & 0.624 \\
\hline Company understands my needs & & & 0.568 \\
\hline Company keeps track of my online transactions & & & 0.787 \\
\hline
\end{tabular}


15 Journal of Southeast Asian Research

\begin{tabular}{|c|c|c|c|}
\hline \multirow[t]{2}{*}{ Items } & \multicolumn{3}{|c|}{ Dimensions } \\
\hline & Lower Rates & $\begin{array}{l}\text { Fulfillment of } \\
\quad \text { Service }\end{array}$ & Quality services \\
\hline Website has reasonable price options & 0.345 & & \\
\hline $\begin{array}{l}\text { Websites offers special internet rates which } \\
\text { are } \\
\text { lower than the normal rates }\end{array}$ & 0.689 & & \\
\hline The site often offers attractive discounts & 0.376 & & \\
\hline The site offers attractive promotions & 0.357 & & \\
\hline $\begin{array}{l}\text { Services are usually priced lower than that of } \\
\text { offered } \\
\text { by other competitors }\end{array}$ & 0.776 & & \\
\hline $\begin{array}{l}\text { Information displayed on the website reflect } \\
\text { real } \\
\text { service quality of the hotel }\end{array}$ & & 0.872 & \\
\hline $\begin{array}{l}\text { Information displayed on the website reflect } \\
\text { the } \\
\text { real condition of the hotel }\end{array}$ & & 0.870 & \\
\hline The service is packaged well & & & 0.541 \\
\hline The service package is flexible & & & 0.763 \\
\hline More varieties of services & & & 0.802 \\
\hline $\begin{array}{l}\text { Services offered are up-to-date with current } \\
\text { trend }\end{array}$ & & & 0.667 \\
\hline
\end{tabular}

